\title{
LITERATURE IN MEDICAL TEACHING
}

THE CRUCIAL IMPORTANCE OF LITERATURE IN THE EDUCATION OF MEDICAL STUDENTS

JOSEP ELADI BAÑOS AND ELENA GUARDIOLA

Recent years have seen an increase in the use of literature in the medical context with different objectives. Firstly, its use as a pedagogical tool for medical students has helped to improve essential professional competencies that are difficult to teach via traditional education in biology alone. Secondly, personal stories have become a very interesting way to understand how patients live with their disease. Finally, the usefulness of literary work as a tool for enhancing improvements in the quality of life of patients is starting to be recognised. In conclusion, literature constitutes an important educational element that can improve the doctor-patient relationship because it facilitates better understanding of illnesses.

Keywords: medicine, literature, medical teaching, dehumanisation, humanities.

Humanities studies are the hormones that act as a catalyst for thinking and humanise the practice of medicine.

(William Osler, The old humanities and the new science)

\section{A LONG BIDIRECTIONAL RELATIONSHIP}

Many elements of medicine and literature make comfortable bedfellows when put together. The main objective of medicine is the relief of human suffering, either curing diseases or at least softening the symptoms that cause distress to those who experience them. Literature has many objectives. One of the main ones is to describe elements that cause concern - and sometimes also suffering to humans. Thus, some universal literary masterworks have explored these situations and interpreted the behaviour of human beings in more (or less) extreme situations. This becomes evident when considering the work by Sophocles, Shakespeare, Cervantes, Tolstoy, Ibsen, and Montaigne, among others.

Why should medicine be interested in literature? There might be many reasons to explain this. Firstly, it is important to remember that physicians were traditionally educated individuals within society. In fact, they were the first professionals to be educated in Western universities, starting from the thirteenth century. Secondly, clinical experience is often too intense to be understood and accepted by following only biological patterns. Finally, a narrative can include nuances that are absent from the traditional medical discourse.

These shared interests explain the fact that many doctors have devoted much of their lives to literature. Among those who are still alive, we must mention Sherwin Nuland, Robin Cook, António and Nuno Lobo Antunes, Stephen Bergman (Samuel Shem), Martin Winckler, Atul Gawande, and Thierry Serfaty. In Catalonia, and to mention but a few, we must remember Alejandro Arís, Jesús García-Sevilla, and Amàlia Lafuente. In fact, many are known precisely for their dedication to literature, and we dare to suggest that in many

cases, readers may be unaware of the initial medical profession of these authors. It must be said, however, that this phenomenon knows neither time nor country: it appears to be timeless and is, apparently, universal.

Where does physicians' interest in literature come from? There is no one answer to this question, but Fernando Navarro may have the answer which has 
been conceptualised the most so far (Navarro, 1999). Navarro - also a doctor - maintains that human contact and the need to escape can explain this habit. Regarding the former, frequent contact with misery and social injustice, vital contact (pain, disease, suffering, loneliness, sexuality, and insanity), and intimate contact (physical and emotional closeness) can lead to a desire to write about one's observations as fiction or fact. In addition, in some cases we find a need for a simple, cathartic, or transcendental escape. But why is this need stronger in medical doctors than other health care professionals? Perhaps because physicians' deeply-rooted writing habit (writing clinical records, reports, epicrises, scientific papers, books, etc.) forms part of their daily routine, also because the practice of medicine is an endless source of good arguments that doctors can share, and this allows doctors to free themselves of their day-to-day professional stresses, and finally, by vocation. Perhaps some of the people mentioned above were already authors who decided to study medicine, and it is not uncommon for doctor-writers (or writer-doctors) to leave the medical profession shortly after they start writing, although others follow both paths for their entire lives.

The genres cultivated by doctor-writers are numerous. Some delve into fiction related to medical topics, such as Martin Winckler and William Carlos Williams. Others have worked on what could be called advanced popularisation, like Arthur Kleinman, Henry Marsh, and Oliver Sacks. The autobiographical contribution is also important, such as the work of Bernard Lown and Nuno Lobo Antunes. Some more clearly stand out in theatre, like Jaume Salom and Arthur Schnitzler. Others are simply great authors in universal literature, including Pío Baroja, John Keats, and Anton Chekhov, and there is no lack of doctorwriters who have become best sellers, for example, Michael Crichton, Robin Cook, Michael Palmer, and Oliver Sacks.

What about literature's interest in medicine? A good number of masterpieces are devoted to aspects we may easily recognise as medicine. Within this group, we can mention Miguel de Cervantes's Don Quixote, several tragedies by William Shakespeare, or some of Molière's comedies. Several works by Thomas Mann, Leo Tolstoy, Marguerite Yourcenar, and John M. Coetzee also cover medical issues in exemplary fashion and have often been used as teaching resources in health sciences.

Therefore, we can conclude that in contrast to other scientific fields, a clear separation - let alone a divorce - has never existed between the worlds of literature and medicine. Further, we might even dare to say that the

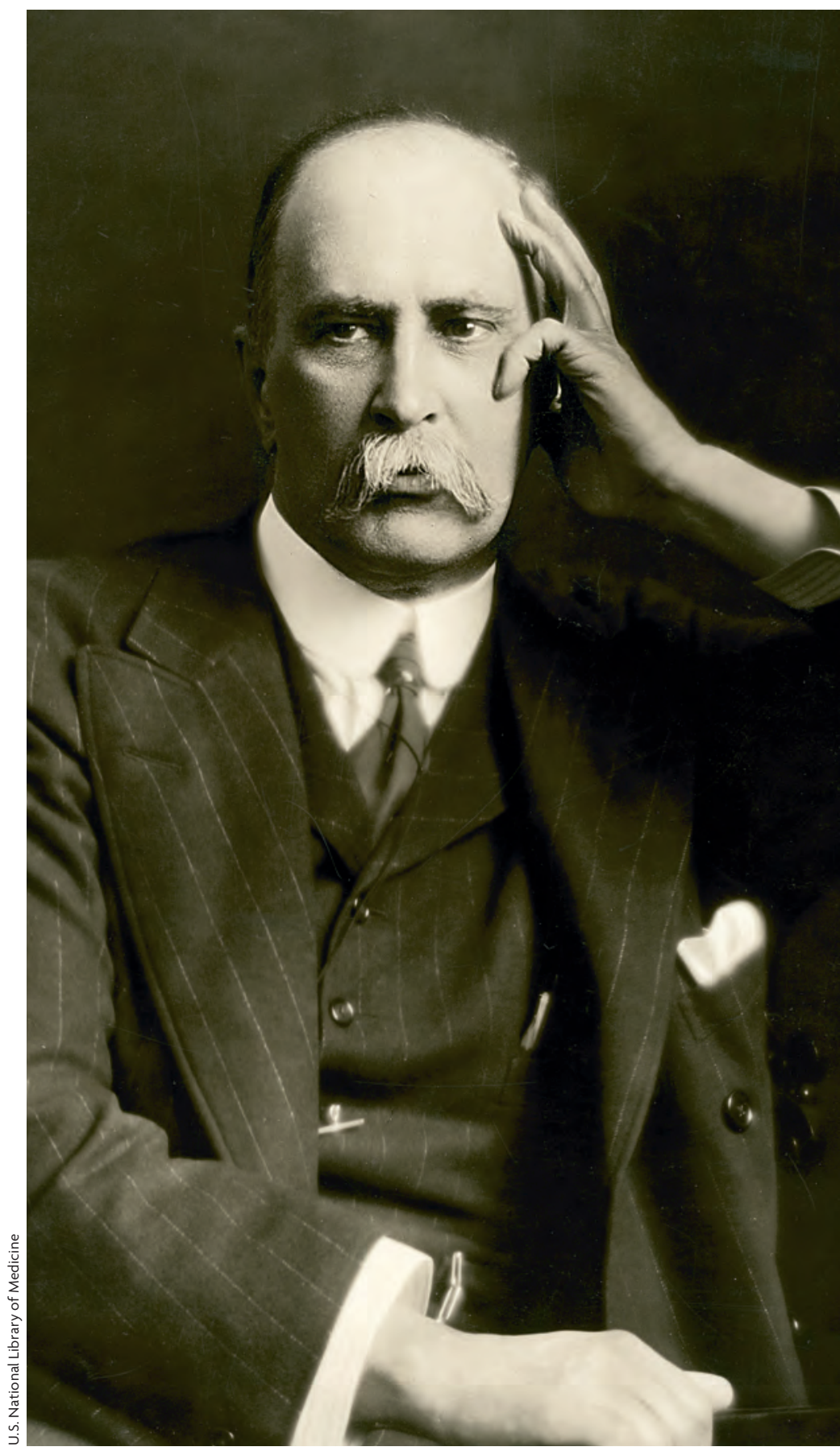

Doctor William Osler (1849-1919) was a great proponent of the use of literature in the training of physicians.

«THE PRACTICE OF MEDICINE

IS AN ENDLESS SOURCE

OF GOOD ARGUMENTS THAT DOCTORS

CAN SHARE» 
relationship between these two worlds has more to do with respect than with ignorance and contempt: human life is too complex to be understood only in terms of the functioning of some molecules or with words formed from a certain inspiration.

\section{LITERATURE IN MEDICAL TEACHING}

Recovering the teaching of humanities in medical curricula has been discussed for decades, but the constant growth of scientific disciplines during the second half of the twentieth century and the success of medical advancements has limited the possibilities for teaching literature, art, or anthropology as part of medical studies because the topics are now too vast. Only moral philosophy, dressed as bioethics, was included without discussion in the traditional history of medicine, but unfortunately, even that has now been removed from many courses. In the United States, concern for the excessive importance allocated to the technological aspects of medicine led to the progressive introduction of humanities programmes into the study of medicine during the 1960s (Hawkins \& McEntyre, 2000). This movement finally culminated in 1972, when Joanne Trautmann Banks became the professor of literature at the College of Medicine at the Pennsylvania State University. This event received support years later when the journal Literature and Medicine was first published. It established a new discipline for the confluence of two fields that were apparently separated from the academic point of view.

Many reasons have been suggested for the use of literature subjects in medical studies (Hawkins $\&$ McEntyre, 2000). The first is that literary texts have many interpretations, even contradictory ones, and these can allow doctors to better understand the patients' experience of living with their diseases. The second, is that reading and debating might lead professionals to face their own prejudices, biases, and predetermined ideas, all of which can obstruct the adequate understanding of each patient's situation. The third involves the ethical aspects of medical intervention, because the interpretation of literary texts can contribute to critical analysis and to moral empathy, skills which are frequently called upon in medical processes. For Craice de Benedetto, Gatti, and Lima da Costa (2011), the most important role the study of literature has for medical students is the

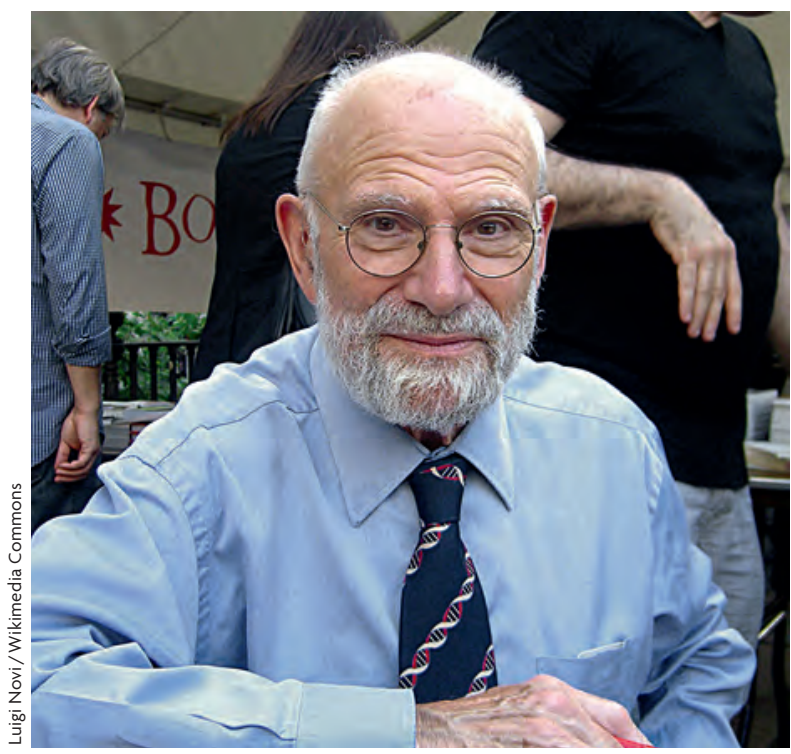

Some doctors, including Martin Winckler and William Carlos Williams, have delved into fiction related to medical topics. Others have worked on what could be called advanced popularisation, for example Arthur Kleinman, Henry Marsh, and Oliver Sacks (pictured).

fact that it can help them to better understand how empathy is perceived, i.e., they better comprehend the life and experiences of their patients and can use this understanding to help put their patients at ease. Finally, a very relevant facet is the consideration of ethical aspects in a context that allows for an extensive and necessary debate among students.

Squier (2000) described some of the aims and objectives of any potential course in medicine and literature, although those provided are obviously not exhaustive and many other topics can be added to them. One of the most important, in our opinion, is the approach to the emotional aspect of disease, which is often ignored in traditional medical training. This aspect is very important when trying to understand that a disease cannot be exclusively considered a biological alteration: we also need to comprehend how this alteration affects the life of those who suffer from it. Until students acquire clinical experience, access to this knowledge is virtually forbidden, and moreover, it is difficult to convey in traditional theoretical lessons, no matter how hard teachers try.

Reading stimulates emotion, which is one of the most important factors for understanding and storing information and a well-chosen literary text can help 
in this sense. The physical limitations of a heart failure are easier to understand in the first page of Memoirs of Hadrian by Marguerite Yourcenar than in a pathophysiology book; the problems derived from insufficient use of opioids for intense pain are more easily comprehended by reading Portrait in sepia by Isabel Allende and A very easy death by Simone de Beauvoir than reading a good pharmacology text. In this sense, literary texts become essential complementary elements in the holistic training of medical students. Literature also helps students to analyse and participate in situations of doctor-patient relationship conflicts, as for example, in The case of Doctor Sachs by Martin Winckler or in A taste of my own medicine: when the doctor is the patient by Edward E. Rosenbaum. Finally, literature also helps us to consider diseases from the patient's point of view. Here we could highlight Perder la piel ("Losing your skin") by Marta Allué or The death of Ivan Ilyich by Leo Tolstoy.

In short, there are many reasons to justify the use of literary texts in the study of medicine. Perhaps Hunter, Charon, and Coulehan summarised it most eloquently when they wrote:

As a complement to studies in epidemiology and abnormal human biology, literature [...] confronts medical students with singular illnesses in particular human beings, engaging the personal response of each student in interpreting human events and choosing an action appropriate to the situation.

(Hunter, Charon, \& Coulehan, 1995, p. 791)

Which texts should be used with medical students remains a widely-debated topic. There are lists (for instance, Baños, 2003) which can serve as a starting point, even though many other works could be added.

\section{DOES LITERATURE HELP TO PRODUCE BETTER DOCTORS?}

There is no unanimous answer to this question. For some, such as William Osler, there is no doubt of the beneficial effect that reading literary works has on doctors' activities. For others, reading literature to improve medical practice is just a refined way of wasting time. Obviously, not every text is appropriate or adequate for all circumstances. However, we tend to align ourselves with Osler, rather than with the critics.

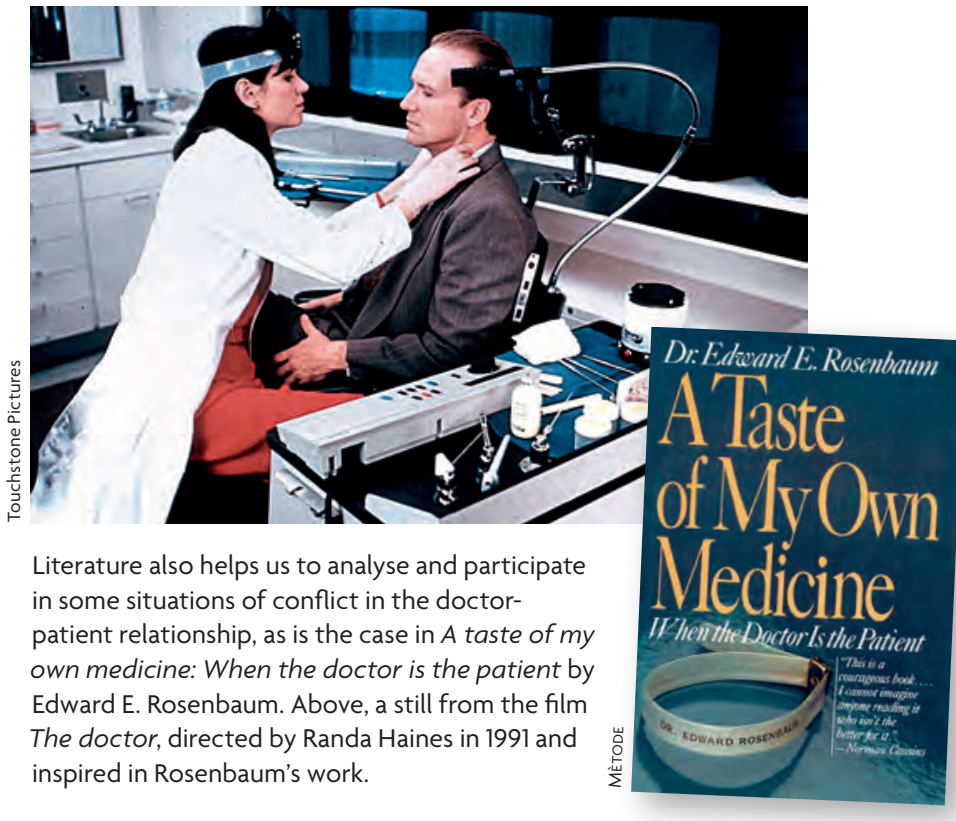

In this sense, Tolstoy's The death of Ivan Ilyich is an excellent example of how even quite a short text can be of great interest, not only to doctors, but also to health sciences professionals (Baños \& Guardiola, 2016). In less than a hundred pages, this story describes the disease and death of a Russian officer (although the text focuses on his life and his passing away corresponds only to the last part of the text). It has been frequently used in health science schools to illustrate and generate debate around very relevant aspects of the professional activity of healthcare providers. Firstly, it is an excellent tool for explaining the human experience of disease, especially its effects on the perception of one's own life, the perception of the disease in the patient's environment, and the psychological process of accepting death. Secondly, it allows us to analyse the experience of treating and taking care of patients, with special attention to the interaction between physical and psychological pain, the use of lies when communicating with patients, and the importance of compassion in health care. Finally, it is an excellent vision of the isolation patients feel at the final stage of their lives. It is a well-rounded work that allows readers to become more empathetic to patients and to understand how a disease eats away at their life and isolates them from their environment - a type of social ostracism that patients with advanced diseases seem to be condemned to. 
The autobiographical experiences of Josep Pla, who suffered a myocardial infarction, José Luis Sampedro, who had an endocarditis, and Yourcenar's fictional description of the heart failure suffered by emperor Hadrian (Baños \& Guardiola, 2015) can also be conceived in the same way. Analysis of these works led us to conclude that these three texts are useful resources for teaching cardiology, beyond merely understanding patients' reactions to facing a disease, and thus, we suggest their use as an educational tool for teaching internal medicine.

In recent years, several published papers have dealt with two aspects connected to literature of interest to medicine: narratives of diseases and socalled bibliotherapy. The first one, also known as writing therapy, refers to the use of texts written

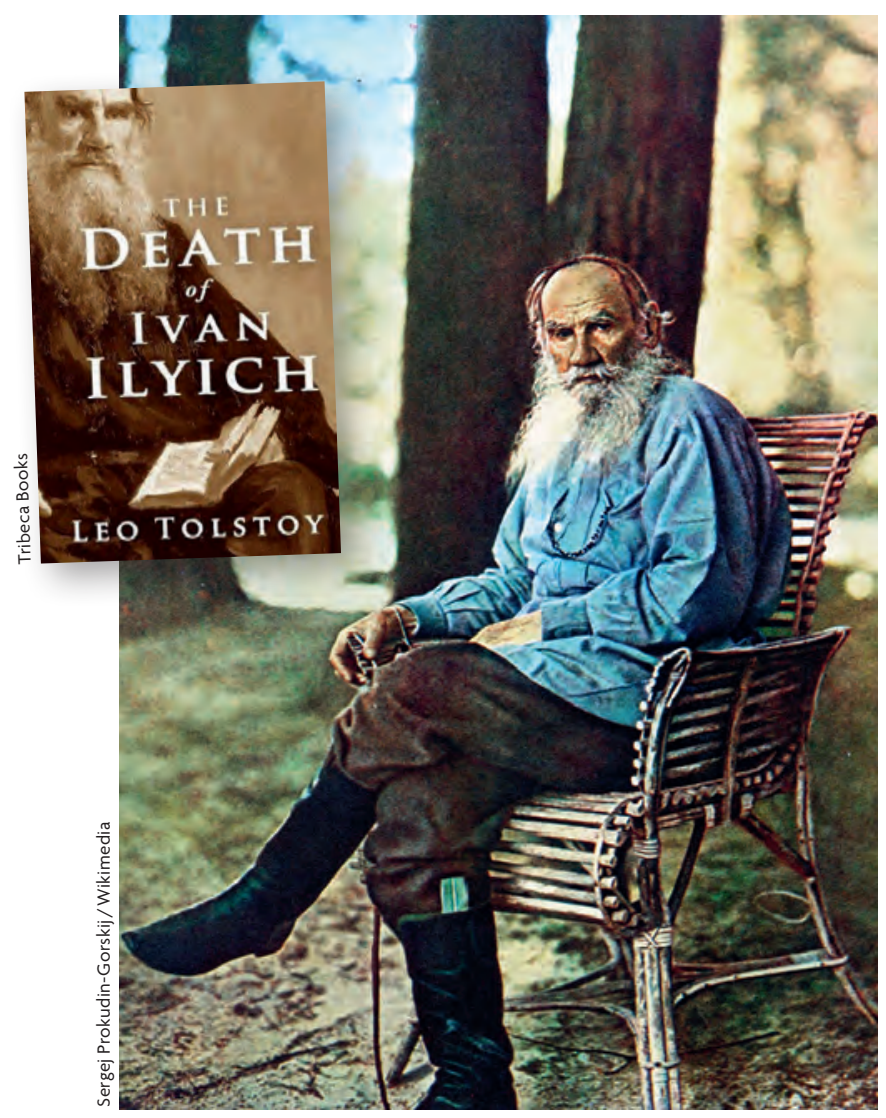

The death of Ivan llyich is an excellent example of how a relatively short text can be of great interest not only to doctors, but also to health sciences professionals. In less than a hundred pages, the story describes the disease and death of a Russian officer. It has often been used in health science schools to illustrate and stimulate debate around very relevant aspects of professional activity. Above, cover of the book and a photograph of Leo Tolstoy. by patients or the first-hand telling of stories about their disease as a tool to help doctors better understand it (Kohan, 2013). Although it was initially used in psychiatric fields, it is now also commonly used in other medical areas, and has led to profound debates about how much of what patients say can be trusted, and the potential use of this diagnostic and therapeutic approach. Interested readers can read Shapiro's (2011) critical review on the potential and limitations of this literary approach. On the other hand, a recent study indicates that, according to medical students at Columbia University, the use of this approach in the context of their training is well perceived (Miller, Balmer, Hermann, Graham, \& Charon 2014).

Bibliotherapy, also known as book therapy (Nadal, 2017), refers to patients reading literary texts as an instrument to improve their understanding of the disease, sometimes through knowledge about the experiences of other affected people (Hidalgo \& Cantabrana, 2017). This approach has aroused considerable interest in recent years and can be a good option to improve, in certain situations, the state of mind of some patients (Berthoud \& Elderkin, 2017). In fact, disease is central to the plot of many autobiographical works and this helps to us choose and «prescribe» (recommend) the most appropriate work for each patient.

All of this has generated interest in general medical journals. An editorial in The Lancet, for instance, stated:

Thoughtful reading helps develop the observation, analysis, and reflection that are fundamental to delivering good care. Stories offer opportunities for escapism, but can also examine systems and ethics, and prepare readers for unexpected twists and turns in the plot. [...] To read can mean both to decode a set of symbols and a structure and also to find meaning in a person or a situation. Perhaps in a setting that can sometimes be difficult, frightening, or bizarre, that is the most important reason of all.

(The Lancet, 2015, p. 90)

On another note, JAMA recently announced the creation of a section called The Arts and Medicine and invited readers to submit texts about arts - in the widest sense of the term, understood as humanities and medicine (Guardiola \& Baños, 2016; Young, 2016). These two are examples of a change in the conception of the relationship between medicine and humanistic disciplines, and in the need for them to 


\section{Title suggestions for organising a literature course for medical students}

\section{Psychological impact of the disease}

Tolstoy, L. (1917) [1886]. The death of Ivan Ilyich and other stories. New York: Charles Scribner's Sons.

De Beauvoir, S. (1965) [1964]. A very easy death. New York: Pantheon.

Solzhenitsyn, A. (1968) [1966]. Cancer ward. New York: Dial.

\section{First-person perspectives on the disease}

Sampedro, J. L. [1998]. Monte Sinaí ("Mount Sinai”). Barcelona: Plaza y Janés.

Bauby, J. D. (1997) [1997]. The diving bell and the butterfly. New York: Alfred A. Knopf.

Suárez, M. [2000]. Diagnóstico: cáncer. Mi lucha por la vida ("Diagnosis: cancer. My struggle for life"). Barcelona: Galaxia Gutenberg.

\section{Sociological aspects of the disease}

Cronin, A. J. [1937]. The Citadel. London: Gollancz.

Sontag, S. [1998]. Illness as metaphor. New York: Farrar, Straus and Giroux.

Sacks, O. [1989]. Seeing voices: A journey into the world of the deaf. Berkeley: University of California Press.

\section{Medicine as a profession: the doctor-patient relationship}

Shem, S. [1978]. The House of God. New York: Richard Marek Publishers.

Winckler, M. (2000) [1998]. The case of doctor Sachs. New York: Seven Stories Press.

Broggi, M. [2001]. Memòries d'un cirurgià ("Memories of a surgeon"). Barcelona: Ed. 62.

\section{Limits of medical research}

Shelley, M. J. [1818]. Frankenstein or the modern Prometheus. London: Lackington, Hughes, Harding, Mavor, \& Jones.

Van der Meersch, M. (1948) [1943]. Bodies and souls New York: Pelegrini \& Cudahy.

Palmer, M. [1991]. Extreme measures. New York: Bantam.

In the list of titles, parentheses indicate the year of the first English translation and brackets indicate the original publication year.

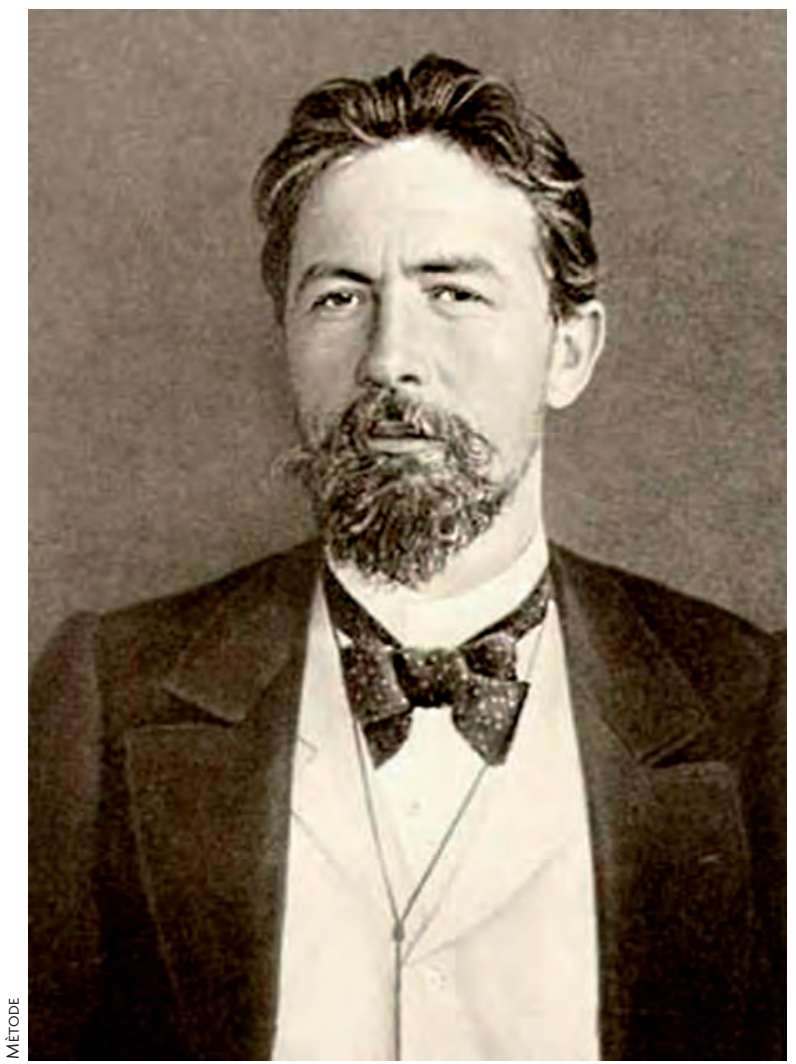

Throughout history, from Ctesias to Chekhov (in the photograph), to the latest contributions by Atul Gawande, there have been many doctor-writers (or writer-doctors), largely because literature offers an escape from the internal conflicts caused by the practice of medicine.

share a common space. The latter are here to stay permanently as a - significant - part of the former.

Finally, we cannot fail to quote the highlyrecommended paper by Fitzgerald (2015), titled «Medicine, the greatest of humanities», in which she states:

As the precious time we spend together with them gets less and less, patients may come to be seen as little more than problems to be efficiently solved by following instructions in manuals for maintenance and repairs. And if this happens, medicine will no longer have a proud place among the humanities.

(Fitzgerald, 2015, p. 966)

In a time of clinical guides and therapy protocols, with minimal time for medical encounters, Fitzgerald's claim sounds almost like a prediction.

\section{IN CASE OF DOUBT... CHOOSE CHEKHOV}

This document provides arguments to justify the title. First, medicine and literature reinforce each 


\section{Goals and objectives of a medicine and literature course}

\section{Goals}

- To deepen students' knowledge of both patients' and doctors' expectations in their understanding of the doctor-patient relationship.

- To prepare and motivate students during their training in the techniques necessary for medical consultations.

- To prepare students for their years of clinical practice training by improving their understanding of the psychosocial aspects of disease and helping them to behave empathetically towards their patients.

- To develop a deeper understanding of how human beings communicate.

- To stimulate self-reflection and moral imagination.

\section{Objectives}

- To debate the differences between the psychosocial and the biopsychosocial models of disease.

- To draw the students' perspective of the ideal doctor-patient relationship through an appropriate creative medium.

- To develop hypotheses regarding how a change in perspective in a story can change the events described or their interpretation.

- To compare a fictional story with students' real experience with patients. other and are inseparable in practice. We also want to emphasise the large number of doctor-writers (or writer-doctors) that have existed throughout history -from the distant Ctesias to the latest contributions by Atul Gawande. This bidirectional relationship happens because literature offers an escape from the internal conflicts caused by the practice of medicine. In addition, emotional aspects associated with diseases can be more effectively conveyed through literature than with the traditional pedagogical methods used in medical schools. In this sense, it helps students to consider - from early on in their training - disease from a holistic point of view, as a biological disorder that can have considerable emotional effects. Considering this vision, we have no doubts that patients can benefit from the development of more empathetic professional behaviour towards diseases and the individuals suffering from them. As the critic Simon Leys (quoted by Nadal, 2017), stated: «Between two doctors whose medical qualifications are otherwise equal, I believe I would rather trust the one who has read Chekhov.» $\odot$

\section{REFERENCES}

Baños, J. E. (2003). El valor de la literatura en la formación de los estudiantes de medicina. Educación Médica, 6(2), 93-99. doi: 10.4321/ s1575-18132003000200005

Baños, J. E., \& Guardiola E. (2015). Utilidad de los textos literarios en la docencia de ciencias de la salud: Ejemplos en cardiología. FEM: Revista de la Fundación Educación Médica, 18(1), 5-14. doi: 10.4321/S201498322015000100003

Baños, J. E., \& Guardiola, E. (2016). ¿Leer a Tolstói nos hace mejores médicos? Reflexiones en torno a La muerte de Iván Illich. Revista de Medicina y Cine, 12(3), 170-176.

Berthoud, D., \& Elderkin, S. (2017). Manual de remedios literarios. Cómo curarnos con libros. Madrid/Barcelona: Siruela/Círculo de Lectores.
Craice de Benedetto, M. A., Gatti, G., \& Lima da Costa, D. (2011). La literatura como recurso didáctico en la formación humanista de los estudiantes de medicina. Atención Familiar, 18(3), 59-62.

Fitzgerald, F. (2015). Medicine: The greatest of humanities. Journal of Pain and Symptom Management, 49(5), 964-966. doi: 10.1016/j. jpainsymman.2014.12.014

Guardiola, E., \& Baños, J. E. (2016). «Del médico que no sabe más que medicina...» o la publicación de artículos no médicos en revistas médicas. Revista de Medicina y Cine, 12(4), 193-195.

Hawkins, A. H., \& McEntyre, M. D. (2000). Introduction. Teaching literature and medicine: A retrospective and a rationale. In A. H. Hawkins, \& M. D. McEntyre (Eds.), Teaching literature and medicine (pp. 1-25). New York: The Modern Language Association.

Hidalgo, A., \& Cantabrana, B. (2017). Efectos terapéuticos de la lectura. Revista de Medicina y Cine, 13(2), 75-88.

Hunter, K. M., Charon, R., \& Coulehan, J. L. (1995). The study of the literature in medical education. Academic Medicine, 70(9), 787-794.

Kohan, S. A. (2013). La escritura terapéutica. Claves para escribir la vida y la creación literaria. Barcelona: Alba editorial.

Miller, E., Balmer, D., Hermann, N., Graham, G., \& Charon, R. (2014). Sounding narrative medicine: Studying students' professional identity development at Columbia University College of Physicians and Surgeons. Academic Medicine, 89(2), 335-342.

Nadal, J. (2017). Libroterapia. Leer es vida. Barcelona: Plataforma editorial.

Navarro, F. A. (1999). Viaje al corazón de uno mismo. ¿Por qué demonios escriben tanto los médicos? Madrid: Roche.

Shapiro, J. (2011). Illness narratives: Reliability, authenticity and the empathic witness. Medical Humanities, 37, 68-72. doi: 10.1136/ jmh.2011.007328

Squier, H. A. (2000). Teaching humanities in the undergraduate medical curriculum. In T. Greenhalgh, \& B. Hurwitz (Eds.), Narrative based medicine (pp. 128-139). London: BMJ Books.

The Lancet. (2015). Literature and medicine: Why do we care? The Lancet, 385(9963), 90. doi: 10.1016/S0140-6736(15)60004-6

Young, R. K. (2016). Introducing The Arts and Medicine. JAMA turns another page. JAMA, 316(13), 1365. doi: 10.1001/jama.2016.14822

Josep Eladi Baños. PhD in Medicine and Full Professor of Pharmacology at the Pompeu Fabra University (Barcelona, Spain).

Elena Guardiola. $\mathrm{PhD}$ in Medicine and Fellow in the Department of Experimental and Health Sciences at the Pompeu Fabra University (Barcelona, Spain). 